\title{
Synthesis of Some Heterocyclic Compounds Via Cyclization of Imidoyl Chloride
}

\author{
G. T. Sedeek \\ Department of chemistry / College of Education \\ University of Mosul
}

Received

13 / $11 / 2011$
Accepted

07 / 03 / 2012

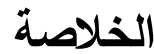

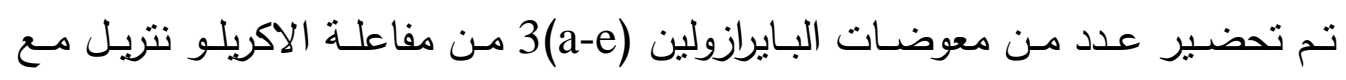

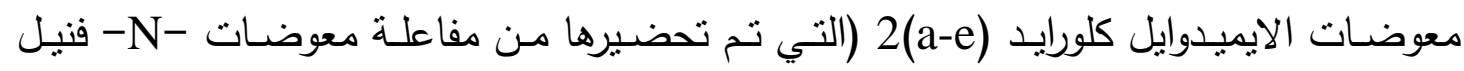
هايدرازايد (a-e) مـع خماسي كلوريد الفسفور) وبإمرار غاز كلوريد الهيدروجين في الايثانول

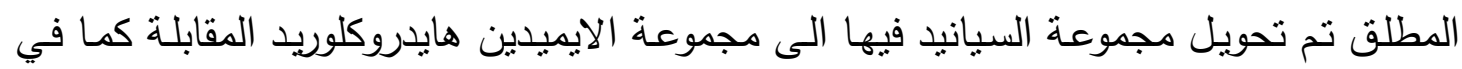

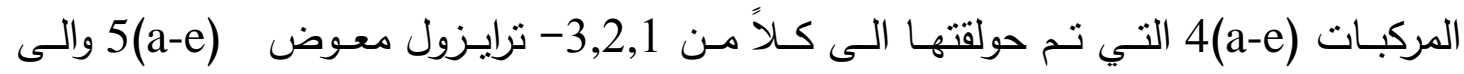
1,2,3,4 نرايزول معوض والى الايميدازول (d,e) باستخدام بارا - نترو فنيل فيل هايدرازايد، أزيد الصوديوم و انلين ثنائي الأمين على التوالي.

\section{Abstract}

Some substituted pyrazoline 3(a-e) were prepared from the reaction of acrelonitril with some substituted imidoyl chloride 2(a-e) (which prepared from substituted - $\mathrm{N}$ - phenyl hydrazide 1(a-e) on treatment with phosphorous penta chloride). Compounds $3(\mathrm{a}-\mathrm{e})$ were then transformed into the corresponding imidate hydrochloride $4(\mathrm{a}-\mathrm{e})$ during the reaction with hydrochloric acid in absolute ethanol. Compounds 4(a-e) were allowed to react with either $\mathrm{p}$ - nitro phenyl hydrazide, sodium azid or ethylene diamine giving the corresponding 1,2,3 - substituted triazoles $5(\mathrm{a}-\mathrm{e}), 1,2,3,4-$ substituted tetrazoles $6(\mathrm{~d}, \mathrm{e})$ and imidazoles $7(\mathrm{~d}, \mathrm{e})$ respectively.

\section{Introduction}

Imidoylations of organic compounds enable the preparation of wide variety of compounds classes. Thus, imidoylation at nitrogen are used for the preparation of amidines, guanidines, and N-substituted derivatives $^{(1)}$. Imidoyl chloride could be prepared by several methods the 
imidoyl chloride can be prepared by treatment of the corresponding amides with phosgene, oxalyl chloride.

Or phosphorous penta chloride ${ }^{(2)}$ chlorination of tertiary amines and of the acyl derivatives of primary and secondary amines at high temperature $\left(\sim 200^{\circ}\right)$ gives imidoyl chloride ${ }^{(3)}$ and chlorination of isothyocyanates, thioamides give these ${ }^{(4,5)}$. The most popular method is the reaction of anilide and phosphorus penta chloride which was first investigated by Sohn, Muller and Mosetting ${ }^{(6,7)}$. Among the reactions of imidoyl is the elimination of hydrogen halide from N-Benzyl halides giving the corresponding nitratile yields; some cycloaddition reactions of this system lead to the formation of compounds such as pyrrole, iminazole and oxazole series ${ }^{(8)}$. Derivatives of pyrazoles and 1, 2, 3 triazole pharmacotherapy gave displayed abroad spectrum of biological activities, anti-inflammatory, anti-fungal, anti-arrhythmic, tranquilizing, muscle relaxing, psycho analeptic, anticonvulsant, mono amine oxidase inhibiting, anti-diabetic and anti bacterial activities ${ }^{(9)}$. Chemotherapeutic importance of imidazole derivatives is well recognized, some 5substituted triazeno imidazole-4- carboxamides has been founded to have potential anti cancer agents ${ }^{(10)}$. The effectiveness of condensed heterocyclic containing pyridine, pyrmidine, thiazole, imidazole rings acts as anti depressants ${ }^{(11)}$ and anti hermitic agents ${ }^{(12)}$. Dihydro Folate and imidazole derivatives such as metronidazole, secnidazole ${ }^{(13)}$, the classes of compounds belong to the hydroxyl and alkoxy containing imidazole class were found to have anti fungal properties ${ }^{(14,15)}$.

Pyrazole and benzamidazole ring have drawn much considerable, interest and were found to be used as a source of endless research both in nature (such as amino acid, histidine, vitamin B12, component of DNA base structure and purines, histamine, biotin) this finding obviously important in pharmaceutical investigation ${ }^{(16,17)}$. Iminazoles formed from certain unstable bisimidoyl halides based on oxalis acid ${ }^{(18)}$ and quinolines are produced by self-condensation of certain $\mathrm{N}$-aryl imidoyl halides ${ }^{(19)}$.

\section{Experimental}

Synthesis of (substituted - N-phenyl hydrazide) $)^{(20)} \mathbf{1}$ (a-e).

Substituted acid chloride (0.05 mole) was added drop wise to a solution of phenyl hydrazine (5.3 gm, 0.05 mole) in $50 \mathrm{ml}$ pyridine with continuous stirring. After about 2 hrs., the reaction mixture poured on to crushed ice (about $100 \mathrm{gm}$ ) the resulted hydrazide was collected and recrystallized from ethanol giving crystals with melting points, $(183-184)^{\circ} \mathrm{C}$ for $1 \mathrm{a},(180-182)$ for $1 \mathrm{~b},(213-215)$ for $1 \mathrm{c},(235-237)^{\circ} \mathrm{C}$ for $1 \mathrm{~d}(152-154)$ for $1 \mathrm{e}$.

Synthesis of (substituted-N-phenyl amino imidoyl chloride) $2(\mathrm{a}-\mathrm{e})^{(21)}$

Compounds 1(a-e) (0.05 mole) and phosphorous penta chloride (0.05 mole) in $25 \mathrm{ml}$ of dry ether and refluxed for $24 \mathrm{hrs}$ under anhydrous 
condition. After the reaction has been completed it was cooled and a solution of $(15 \mathrm{gm})$ of phenol in $(25 \mathrm{ml})$ of dry ether and methanol $(40 \mathrm{ml})$ was then added. The solvent was evaporator to halve its volume. The final mixture was left in cool box 5 days.the product was separated as prisms crystals.

Synthesis of 1-phenyl-3- substituted -5-cyano -2- pyrazoline $^{(21)} 3$ (a-e)

A mixture of acrelonitrile ( 0.01 mole $)$, hydroquinine $(0.01$ mole $)$ compounds 2 (a-e) ( 0.0 mole) in $50 \mathrm{ml}$ dry benzene was refluxed for 2 hours with continuous stirring. The hot solution was filtered off and the filtrate was evaporated under reduced pressure. The residue was crystallized from methanol giving prisms crystals.

Synthesis of (1-phenyl -3- substituted-2- pyrazoline-5- yl) ethyl imidate hydrochloride ${ }^{(22)} 4$ (a-e)

A mixture of ( 0.01 mole) of compounds $3(\mathrm{a}-\mathrm{e})$ was dissolved in $(40$ $\mathrm{ml})$ of dry chloroform and ( $0.1 \mathrm{~mole})$ of absolute ethanol.The mixture was saturated with hydrogen chloride gas with cooling at $0^{\circ} \mathrm{C}$ flask is Stoppard and place in refrigerator for 7 days and then equal volume of dry ether added. The imidate hydrochloride filtered off and directly in further step.

Synthesis of -3- (1-phenyl -3- substituted -2- pyrazoline-5- yl) -5(para nitro phenyl) 1, 2, 4- triazole $^{(23)} 5$ (a-e)

Compounds 4(a-e) (0.01 mole), 4-nitro phenyl hydrazide (1.78 gm, $0.01 \mathrm{~mole})$ and tritely amine (1.01gm, $0.01 \mathrm{~mole})$ in $40 \mathrm{ml}$ ethanol were mixed together. The reaction mixture was refluxed for (12 hrs), cooled and filtered off. The residue was re-crystallized from water.

Synthesis of 5- (1-phenyl -3- substituted -2- pyrazoline -5- yl) -1, 2, 3tetrazole $^{(22)} 6(\mathrm{~d}, \mathrm{e})$

A mixture of $(0.01$ mole $)$ of compounds $4(\mathrm{~d}, \mathrm{e})$ and $(0.6 \mathrm{gm}, 0.015$ mole) of sodium azide in $25 \mathrm{ml}$ of acetic acid and was refluxed for $24 \mathrm{hrs}$. Sodium chloride salt was filtered off, evaporation of the solvent to gave a colorless needles.

Synthesis of 2- (1- phenyl -3- substituted -2- pyrazoline -5- yl) -1, 3imidazoline $^{(22)} 7$ (d,e)

A mixture of $(0.01$ mole) of compounds $4(\mathrm{~d}, \mathrm{e})$ and $(0.6 \mathrm{gm}, 0.01$ mole) of ethylene diamine in $15 \mathrm{ml}$ of absolute ethanol. The mixture was refluxed for $6 \mathrm{hrs}$. Then kept at $0^{\circ} \mathrm{C}$ overnight. The small amount of salt was filtered off. The filtrate then was evaporated and the residual recrystallized from water. The melting point IR data and \% yield of the synthesis of compounds were showed in table (1). 

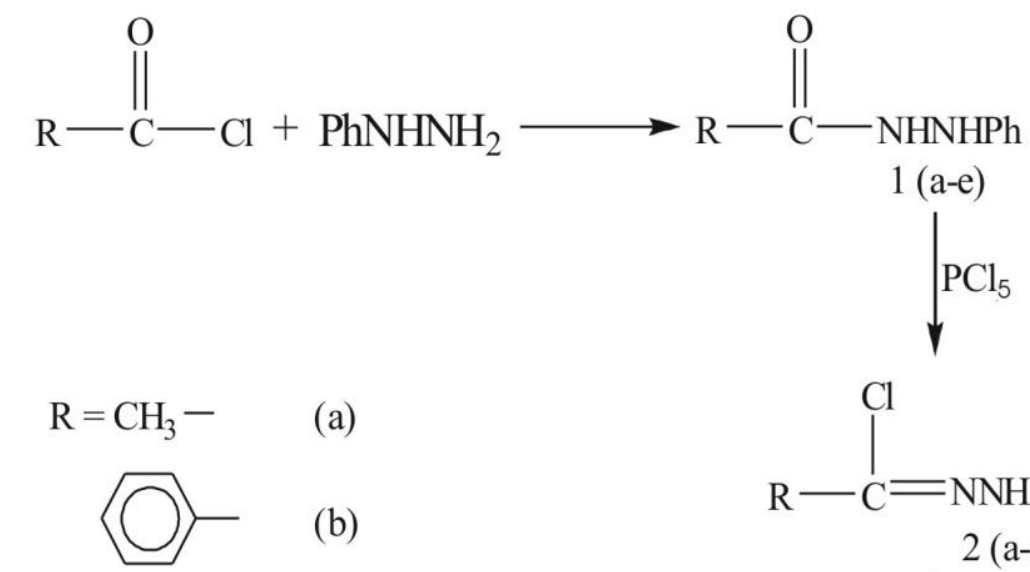

(a)

(b)<smiles>[R]C(Cl)=NNc1ccccc1</smiles><smiles>Cc1cc([N+](=O)[O-])cc([N+](=O)[O-])c1</smiles>

(c)

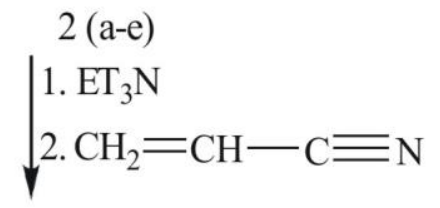<smiles>Cc1ccc(C)cc1</smiles><smiles>[R]C1=NN(c2ccccc2)C(C#N)C1</smiles><smiles>Cc1ccc([N+](=O)[O-])cc1</smiles>

(e)

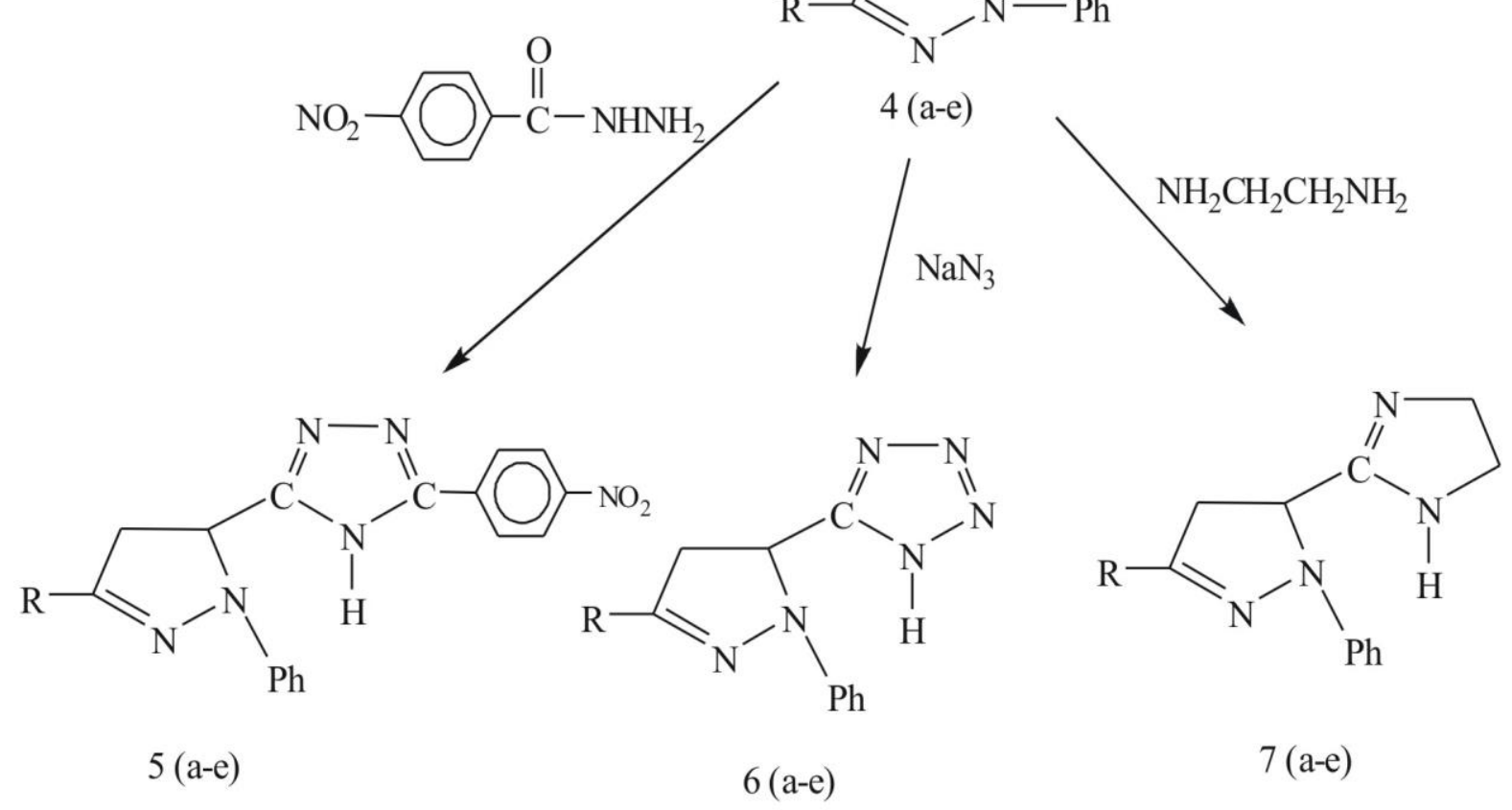

Scheme (1) 


\section{G. T. Sedeek}

Table (1): IR spectra and physical properties of compound (2-7)

\begin{tabular}{|c|c|c|c|c|c|c|c|}
\hline Compound No. & M.P. & $\begin{array}{c}\text { Yield } \\
\%\end{array}$ & $\mathrm{C}-\mathrm{Cl}, \mathrm{C}-\mathrm{O}$ & $\begin{array}{c}\mathrm{C}=\mathrm{C} \\
\mathrm{Ar}\end{array}$ & $\stackrel{\mathrm{O}}{\mathrm{C}}-\mathrm{NH}$ & $\mathrm{C}=\mathrm{N}$ & $\mathrm{C} \equiv \mathrm{N}, \mathrm{N}-\mathrm{H}$ \\
\hline $2 \mathrm{a}$ & $170-171$ & 86 & $765(\mathrm{C}-\mathrm{Cl})$ & 1497 & - & 1605 & 3422 \\
\hline $2 b$ & $91-92$ & 69 & $751(\mathrm{C}-\mathrm{Cl})$ & 1496 & - & 1644 & 3241 \\
\hline $2 c$ & $237-238$ & 82 & $764(\mathrm{C}-\mathrm{Cl})$ & 1491 & - & 1608 & 3423 \\
\hline $2 d$ & $210-211$ & 88 & $765(\mathrm{C}-\mathrm{Cl})$ & 1491 & - & 1609 & 3449 \\
\hline $2 \mathrm{e}$ & $134-136$ & 90 & $754(\mathrm{C}-\mathrm{Cl})$ & 1487 & - & 1636 & 3442 \\
\hline $3 a$ & $189-190$ & 67 & - & 1492 & - & 1626 & $2118(\mathrm{C} \equiv \mathrm{N})$ \\
\hline $3 b$ & $84-86$ & 72 & - & 1472 & - & 1629 & $2230(\mathrm{C} \equiv \mathrm{N})$ \\
\hline $3 c$ & $73-75$ & 72 & - & 1475 & - & 1627 & $2358(\mathrm{C} \equiv \mathrm{N})$ \\
\hline $3 d$ & $203-204$ & 76 & - & 1466 & - & 1618 & $2298(\mathrm{C} \equiv \mathrm{N})$ \\
\hline $3 \mathrm{e}$ & $220-222$ & 80 & - & 1441 & - & 1646 & $2272(\mathrm{C} \equiv \mathrm{N})$ \\
\hline $4 a$ & 117-119 & 77 & $1116(\mathrm{C}-\mathrm{O})$ & 1495 & - & 1644 & 3423 \\
\hline $4 b$ & $169-198$ & 75 & $1101(\mathrm{C}-\mathrm{O})$ & 1437 & - & 1602 & 3325 \\
\hline $4 c$ & $90-92$ & 76 & $1036(\mathrm{C}-\mathrm{O})$ & 1475 & - & 1610 & 3420 \\
\hline $4 d$ & $66-68$ & 85 & $1066(\mathrm{C}-\mathrm{O})$ & 1491 & - & 1609 & 3422 \\
\hline $4 \mathrm{e}$ & $44-46$ & 80 & 1025 & 1492 & - & 1608 & 3446 \\
\hline $5 a$ & $238-240$ & 67 & - & 1469 & - & 1626 & 3444 \\
\hline $5 b$ & $232-234$ & 68 & - & 1495 & - & 1601 & 3327 \\
\hline $5 c$ & 207-209 & 65 & - & 1494 & - & 1596 & 3205 \\
\hline $5 d$ & $\begin{array}{l}250- \\
251^{\mathrm{d}} \\
\end{array}$ & 70 & - & 1466 & - & 1627 & 3441 \\
\hline $5 e$ & $270-271$ & 73 & - & 1495 & - & 1602 & 3423 \\
\hline $6 \mathrm{~d}$ & $166-167$ & 70 & - & 1493 & 1658 & 1598 & 3442 \\
\hline $6 e$ & 196-198 & 75 & - & 1475 & 1691 & 1599 & 3422 \\
\hline $7 d$ & $201-203$ & 80 & - & 1495 & 1679 & 1602 & 3325 \\
\hline $7 \mathrm{e}$ & $236-238$ & 85 & - & 1492 & 1734 & 1609 & 3445 \\
\hline
\end{tabular}




\section{Results and Discussion:}

As it was mentioned in the introduction there were different methods for the preparation of imidoyle chloride among which is the conversion of the corresponding phenyl hydrazide using $\mathrm{PCl}_{5}$ as chlorinating agent. Scheme (1) shows this transformation into compounds 2(a-e) which was characterized by the main absorption bands as indicated in table (1) compounds 2(a-e) was cycled by acrelonitrile into pyrazoline derivatives $3(\mathrm{a}-\mathrm{e})$ this compounds were characterized by stretching band $(\mathrm{C} \equiv \mathrm{N})$ at (2118-2358). Compounds 4(a-e) were obtained as amidine hydrochloride upon treatment of compounds $3(\mathrm{a}-\mathrm{e})$ with $\mathrm{HCl}$ absolute ethanol. these compounds were characterized by stretching bands $(\mathrm{C}=\mathrm{N})$ absorbed at (1618- 1646) $\mathrm{cm}^{-1},(\mathrm{C}-\mathrm{O})$ band absorbed within the rang at (1036-1116) $\mathrm{cm}^{-1}$, and (N-H) band absorbed at (3241-3449) $\mathrm{cm}^{-1}$.

The 5(a-e) were characterized by the following absorption bands which were indicated in table (1) the band absorbed within the rang (1466-1494) $\mathrm{cm}^{-1}$ belongs to aromatic $(\mathrm{C}=\mathrm{C})$ stretching absorption, the $\mathrm{C}=\mathrm{N}$ stretching were appeared as broad bands (1596-1627) $\mathrm{cm}^{-1}$. While the $(\mathrm{N}-\mathrm{H})$ absorption appeared at (3205-3444) $\mathrm{cm}^{-1}$ compounds 4(a- e) were converted to trizole upon treatment with P-nitro phenyl hydrazide as indicated in the experimental part. These compounds were characterized by the following bands $(\mathrm{C}=\mathrm{C})$ aromatic $(\mathrm{C}=\mathrm{N})$ and $(\mathrm{N}-\mathrm{H})$ absorbed at (1473-1495), (1602- 1644) and (3223- 3446) $\mathrm{cm}^{-1}$. Compounds $6(\mathrm{~d}, \mathrm{e})$ were also obtained on treatment of compounds $4(\mathrm{~d}, \mathrm{e})$ with sodium azide this compounds were also characterize by the main absorption band $(\mathrm{C}=\mathrm{C})$ aromatic $(\mathrm{C}=\mathrm{N})$ and $(\mathrm{N}-\mathrm{H})$ at $(1475-1493),(1598-1599)$ and (3423 - 3442). The final compounds $7(\mathrm{~d}, \mathrm{e})$ were obtained from treatment of compounds $4(\mathrm{~d}, \mathrm{e})$ with ethylene diamin. This compounds were characterized by the following main absorption bands $(\mathrm{C}=\mathrm{C})$ aromatic $(\mathrm{C}=\mathrm{N})$ and $(\mathrm{N}-\mathrm{H})$ at $(1492-1495),(1602-1609)$ and $(3325-3445) \mathrm{cm}^{-1}$ and other bands can be shown in table (1). The cyclization mechanism for the formation of compounds 3(a-e) from 2(a-e) could be represented by simple addition of substituted of $-\mathrm{N}$ - phenyl amino imidoyl chloride Moiety 2(a-e) (anilinum ion proton) on the alken double bond of acrelonitrile. Followed by nucleophilic substitution of the enolate ion to the chloride of the above moiety, compounds 4(a-e) were reacted with 4nitrophenyl hydrazide giving compounds 5(a-e) according to the following proposed mechanism: 
<smiles>[R]C1=NN(c2ccccc2)C(C(=N)Cl)C1</smiles><smiles>[NH3+]NC(=O)c1ccc([N+](=O)[O-])cc1</smiles>

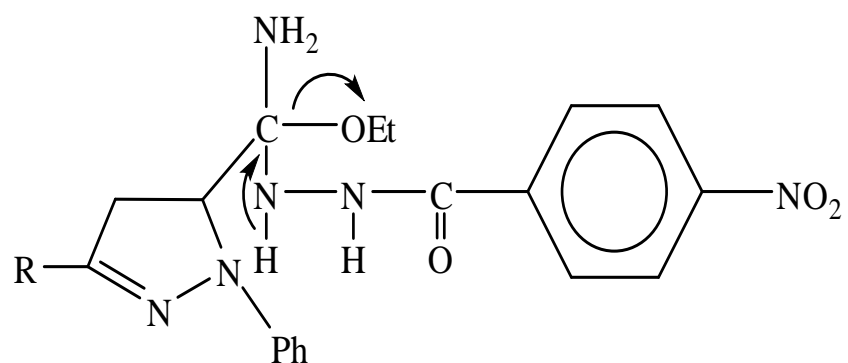<smiles>[R]C1=NN(c2ccccc2)C(/C(N)=N/NC(=O)c2ccc([N+](=O)[O-])cc2)C1</smiles><smiles>[R]C1=NN(c2ccccc2)C(C2=NN([2H])C(O)(c3ccc([N+](=O)[O-])cc3)N2[Y])C1</smiles><smiles>[R]C1=NN(c2ccccc2)C(c2nnc(-c3ccc([N+](=O)[O-])cc3)[nH]2)C1</smiles> 


\section{References}

1) A. R. Katrilzky, N.M. Khashab, and E. Todadze Arkivoc, 16, 25, (2008).

2) T. Kawamura, M. Terashita, E. Naka, Chem, Pharm. Bull 49, 268 (2001).

3) P. Som, K. Terashita, D.Boykin. Chem. Abstr, 13990, (2004).

4) E. Sell and G. Zierold, J. Chem. Soc., 191 (1940)

5) K. Heyns and W. Von Bebenburg, Chem. Ber., 89,1303 (1965)

6) A. Soon and E. Muller, J. Am. Chem. Soc., 75, 657, 1953.

7) E Mosetting, J. Org. Reactions, 8, 240 (1959).

8) R. Huisgen, Angew. Chem. Intern. Ed. Engl., 2, 565, (1963).

9) H.C. Kolob, M.F. Finn, K.B. Angew. Chem. Int. Ed. 40, 2004, (2003).

10) Y.F. Shealy, C.A. Krauth and J.A. Montagomery. J. Org. Chem., 27, 2150, (1962).

11) J.M. Sigh, J. Med. Chem., 13, 1019, (1970).

12) C.J. Sharpe, R.S. Shadbolt, A. Ashferd and J.W. Row, J.Med. Chem., 14, 977, (1971).

13) L.F. Miller and R.E. Bambury, J. Med. Chem., 15, 415, (1972).

14) Z. ASRARI. ph. thesis Shiraz University, 2003.

15) M. Ress Grimmett "imidazole and benzimidazole synthesis" (1997), Academic Press Inc., London, p. 5.

16) J. Louie, J.E. Gibby, M.V. Fornourth and T.N. Tekarec, J. Am. Chem. Soc. (2002), 124, 14188, Internet.

17) H.A. Doung, M.J. Cross and J. Louie, organic letters, (2004), 6, 4679, Internet.

18) R. Bonnett, "The chemistry of the carbon - Nitrogen Double bond", Ed by S.W. Patai, New york, 1970, P. 731.

19) H. Hohschmidt, Angew. Chem. Intern. Ed Engl., 1,632 (1962).

20) H.L. Yale, K Losee, J. Martins, M. Hosing, F.M. Perry and J. Bernstein (1953) "Chemotherapy of experimental tuberculosis, VIII the synthesis of acid hydrazides, their derivatives and related compound", J. Am. Chem. 75, (1933).

21) R. Huisgen, M. Seidel, G. Wallbillicw and H. Knupfler, Tetraheron, 1962, 17, 3.

22) R. Sandler and Wikero, "Organic Functional Group Preparation", Vol. (3). Academic Press Inc., London, Ltd., 1972.

23) C.D. Hurd and L.L. Gershbein, J. Am. Chem. Soc., 1947, 69, 2328. 